\title{
RIGHT ATRIAL HYDATID CYST ASSOCIATED WITH MULTIPLE ORGAN INVOLVEMENT: CASE REPORT
}

\author{
T. Aydoğdu, MD, ${ }^{\mathrm{a}}$ N. Şahin, MD, ${ }^{\mathrm{a}}$ V. Ulusan, MD, ${ }^{\mathrm{a}} \mathrm{F}$. Gürpınar, MD, ${ }^{\mathrm{a}} \mathrm{C}$. Türkay, MD, ${ }^{\mathrm{b}}$ and Ö. Bayezid, MD, ${ }^{\mathrm{b}}$ Antalya, Turkey
}

Hydatid disease is a parasitic infection caused by Echinococcus granulosus, characterized by cystic lesions in the liver, lungs, and rarely in other parts of the body. ${ }^{1}$ Hydatid cyst in the heart is uncommon, with cardiac involvement occurring in about $0.2 \%$ to $3 \%$ of all cases of human hydatidosis. ${ }^{2}$ Hydatid cysts involving the heart have the following predominant locations: the left ventricle, $75 \%$; the right ventricle, $18 \%$; and the interventricular septum, $7 \%$. Occurrence in the atrium has been reported rarely. ${ }^{3}$ The incidence of hydatid disease in children is extremely uncommon. We report a case of multiorgan involvement, including hydatid cyst of the right atrium, that was successfully treated surgically.

Clinical summary. A 13-year-old girl was admitted to the hospital with hemoptysis and chest pain on exertion of 3 months' duration. The hemoptysis had recurred for 10 days before admission. On physical examination, the blood pressure was $100 / 70 \mathrm{~mm} \mathrm{Hg}$, heart rate 96 beats $\mathrm{min}^{-1}$, and on auscultation of the lungs, crackling rales were audible especially on the left side. Arterial blood gases were as follows: $\mathrm{pH}, 7.46 ; \mathrm{PCO}_{2}, 33.3 \mathrm{~mm} \mathrm{Hg} ; \mathrm{Po}_{2}, 91 \mathrm{~mm} \mathrm{Hg}$; oxygen saturation, $97.6 \%$; base excess, $+1.0 \mathrm{mmol} \mathrm{L} \mathrm{L}^{-1}$; and bicarbonate $\left(\mathrm{HCO}_{3}\right), 23.8 \mathrm{mmol} \mathrm{L}-1$. The chest $\mathrm{x}$-ray film demonstrated a normal cardiac image, a round opacity well delineated on the left side, and nonspecific small opacities on the right side of the lung (Fig 1). The serial electrocardiograms showed no abnormalities. On 2-dimensional echocardiography, a cyst with multiple loculations was apparent within the posterior wall of the right atrium (Fig 2). Computed tomography and magnetic resonance imaging confirmed the diagnosis as a multilobular cystic lesion. In addition, computed tomography showed another cyst in the left kidney and multiple cysts in the lungs. The enzymelinked immunosorbent assay for Echinococcus was positive (1/1600). After 2 weeks of therapy with albendazole, 400 $\mathrm{mg}$, cardiac surgery was planned on an emergency basis. One day before the surgical procedure, the massive hemoptysis occurred suddenly and the patient was rapidly admitted to the intensive care unit (ICU). In the ICU, a cystic mass within the posterior wall of the right atrium that was detected during the diagnostic investigations was unapparent on 2-dimensional echocardiography. It was thought that

From the Department of Anesthesiology and Reanimation ${ }^{\mathrm{a}}$ and the Department of Cardiovascular Surgery, ${ }^{\mathrm{b}}$ Faculty of Medicine, Akdeniz University, Antalya, Turkey.

J Thorac Cardiovasc Surg 2001;121:1009-11

Copyright () 2001 by The American Association for Thoracic Surgery

$0022-5223 / 2001 \$ 35.00+0 \quad \mathbf{1 2 / 5 4 / 1 1 2 6 2 8}$

doi:10.1067/mtc.2001.112628

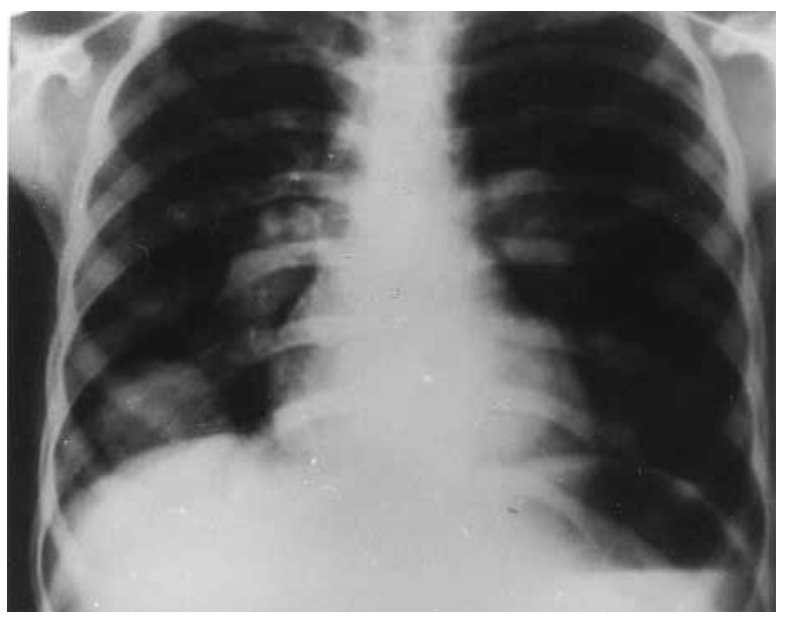

Fig 1. Chest x-ray film.

the hydatid cyst had ruptured. Surprisingly, the patient did not have an anaphylactic reaction and hemoptysis did not recur while she was in the ICU. For premedication, midazolam $0.05 \mathrm{mg} \mathrm{kg}^{-1}$ ) was given intravenously in the ICU before the patient was taken to the operating room. General anesthesia was induced with fentanyl $\left(50 \mu \mathrm{g} \mathrm{kg}^{-1}\right)$ and $2.5 \%$ thiopental $\left(5 \mathrm{mg} \mathrm{kg}^{-1}\right)$; for safe endotracheal intubation, vecuronium $\left(0.1 \mathrm{mg} \mathrm{kg}^{-1}\right)$ was given intravenously. For maintenance of anesthesia, fentanyl $\left(5 \mu \mathrm{g} \mathrm{kg}^{-1}\right)$ and vecuronium $\left(0.8 \mathrm{mg} \mathrm{kg}^{-1}\right)$ were given as intravenous anesthetics and isoflurane as an inhalation anesthetic.

The operation was performed through a median sternotomy incision. The pericardium was opened, and the heart was cannulated and connected to extracorporeal bypass circulation. Under cold potassium and blood cardioplegic and ischemic arrest, a right atriotomy was performed. The cystic mass had ruptured and could be easily seen within the posterior wall of the right atrium. The wall of the cyst was stretching toward the connecting point of the inferior vena cava and right atrium. The cyst was dissected away successfully. Then, the wall of the right atrium was closed with a Teflon felt support and the patient was removed from the pump-oxygenator, tolerating the operation well. After the operation, the patient admitted to the ICU and was sedated with propofol $\left(30 \mu \mathrm{g} \mathrm{kg}^{-1} \mathrm{~min}^{-1}\right)$. After an uncomplicated postoperative period, medical treatment with albendazole was continued and the patient was discharged from the hospital 10 days after the operation. The patient remains in a good health.

Discussion. Echinococcosis in human beings is caused by the larval form of Taenia echinococcus, which lives in the gut of the dog, wild canids, and other carnivorous animals. ${ }^{4}$ In its 


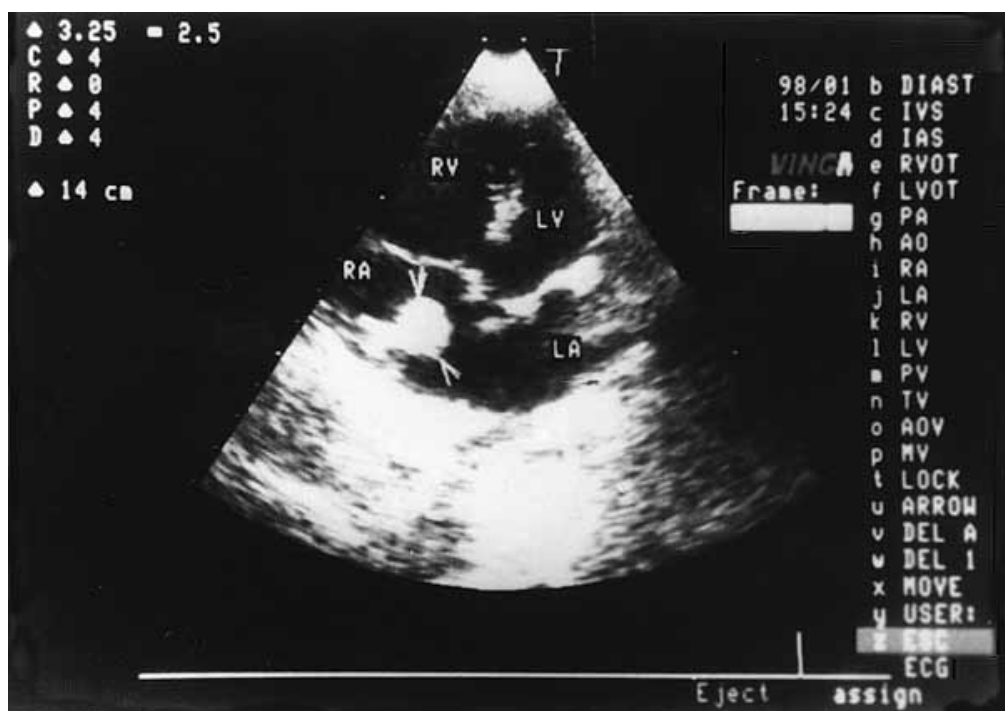

Fig 2. Apical 4-chamber view of 2-dimensional echocardiogram. $R V$, Right ventricle; $L V$, left ventricle; $R A$, right atrium; $L A$, left atrium.

early stages, the echinococcus larva arrives in the left cardiac cavities through either the pulmonary capillary network or the right atrium owing to patency of the foramen ovale. Reaching the coronary arteries, the larva invades the myocardium, requiring 1 to 5 years to attain adult form. ${ }^{5}$

Hydatidosis of the heart is uncommon and is characterized by a high incidence of sudden life-threatening complications. ${ }^{2,6}$ The clinical progress of hydatid disease depends on the location and size of the cyst. Cardiac hydatid cysts may be asymptomatic or may provoke electrocardiographic signs of subepicardial ischemia and conduction disturbance of the His bundle or its branches. ${ }^{7}$ The clinical symptoms induced by hydatid cysts are due to related complications, such as rupture, obstruction, or compression. ${ }^{3,5,8,9}$ Massive pulmonary embolism, hydatid pulmonary hypertension, systemic embolism, and anaphylactic reactions have been reported as a result of rupture of the cyst. ${ }^{2,3,7}$ In our case, the massive hemoptysis occurred without any anaphylactic reaction. The marked incidence of catastrophic complications including sudden death in cardiac echinococcosis emphasizes the need for early diagnosis. ${ }^{6,10,11}$ The techniques of cardiac imaging, either computed tomography or 2-dimensional echocardiography, that are sensitive and useful diagnostic procedures in cardiac echinococcosis have greatly facilitated the detection of cardiac involvement. ${ }^{8,10,11}$

After the diagnosis, because of the location and the risk of rupture with consequent pulmonary embolization, surgery should be performed on an emergency basis. ${ }^{3,5,12}$ In our case, too, cardiac surgery was performed on an emergency basis, and when the heart was opened, rupture of the cyst was easily visible.

It is also important to recognize anaphylactic reactions during surgical procedure so that immediate treatment can be instituted to restore both circulatory competency and cardiac output. Anaphylaxis can be suspected but cannot be proved without specific tests. In our case, during anesthesia, there were no hemodynamic changes and no evidence of an anaphylactic reaction.

We conclude that any child from a region in which echinococcosis is endemic, especially a child having any symptom indicative of echinococcosis, should be carefully examined for a cardiac hydatid cyst. Two-dimensional echocardiography, computed tomography, magnetic resonance imaging, and enzyme-linked immunosorbent assay for Echinococcus were excellent methods for establishing the diagnosis in this case and allowed the immediate correct treatment of this rare condition. Because accidental rupture of $\mu \mu$ dures has serious consequences, anesthesiologists must be aware of the possibility of anaphylactic reactions.

Received for publication Sept 11, 2000; accepted for publication Oct 16, 2000.

Address for reprints: Tülin Aydoğdu, MD, Akdeniz Üniversitesi Tip Fakultesi, Anesteziyoloji ve Reanimasyon Anabilim Dali, 07070 Antalya, Turkey.

\section{REFERENCES}

1. Halezeroglu S, Çelik M, Uysal A, Şenol C, Keleş M, Arman B. Giant hydatid cyst of the lung. J Thorac Cardiovasc Surg 1997;113:712-7

2. Mancuso L, Bondi F, Marchi S, Iacona MA, Guernera S, Patane L. Cardiac hydatid disease with clinical features resembling tricuspid stenosis. Am Heart J 1987;113:1234-6.

3. Yekeler I, Koçak H, Aydin NE, Başoğlu A, Okur A, Şenocak H, et al. A case of cardiac hydatid cyst localized in the lungs bilaterally and on anterior wall of right ventricle. Thorac Cardiovasc Surg 1993;41:261-3. 
4. Taratuto AL, Venturiello SM. Echinococcosis. Brain Pathol 1997;7:673-9.

5. Macedo AJ, Magalhaes MP, Tavares NJ, Bento L, Sampayo F, Lima M. Cardiac hydatid cyst in a child. Pediatr Cardiol 1997;18:226-8.

6. Malouf J, Saksouk FA, Alam S, Rizk GK, Dagher I. Hydatid cyst of the heart: diagnosis by two-dimensional echocardiography and computed tomography. Am Heart J 1983;109:605-7.

7. Russo G, Tamburino C, Cuscuna S, Arcidiacono G, Foti R, Grimaldi DR, et al. Cardiac hydatid cyst with clinical features resembling subaortic stenosis. Am Heart J 1983;117:1385-7.

8. Oliver JM, Benito LP, Ferrufino O, Sotillo JF, Nunez L. Cardiac hydatid cyst diagnosed by two-dimensional echocardiography. Am Heart J 1982;104:164-5.
9. Erol Ç, Candan İ, Akalin H, Sonel A, Kervancioğlu C. Cardiac hydatid cyst simulating tricuspid stenosis. Am J Cardiol 1985;56:833-4.

10. Ernst A, Cikes I, Radovanovic N. Two dimensional echocardiographic study of a cardiac hydatid cyst. Am J Cardiol 1983;52:1361-3.

11. Geiger AW, Konertz W, Hindricks G, Hachenberg T, Fahrenkamp A, Scheld H. Echinococcal cyst of interventricular septum: a rare cause of myocardial ischemia. Thorac Cardiovasc Surgeon 1992;40:42-4.

12. Ameli M, Mobarhan HA, Nouraii SS. Surgical treatment of hydatid cysts of the heart: report of six cases. J Thorac Cardiovasc Surg 1989;98:892-901. 